DOI: 10.1515/ausp-2016-0004

\title{
Three Sophisticated Ladies and Their Turns of Discourse: Edith Wharton, Flannery O'Connor, Alice Munro
}

\author{
Anca PEIU \\ University of Bucharest (Romania) \\ Department of English \\ anca.peiu@lls.unibuc.ro
}

\begin{abstract}
My paper focuses on certain "turns of discourse" which can make the main messages of literary masterpieces by Edith Wharton, Flannery O'Connor, and Alice Munro communicate, despite differences in time, space, culture. Thus the label of feminism may be superficial here. What these three writers of canonical world literature share is a fine gift for feminine irony, that is responsible for both their stylistic virtuosity and their thematic choices. I was particularly interested in their intricate views and ways of dealing with the difficulties of the mother-daughter relationship in their exclusively concise short fiction. The horror, (hurt) hubris, and humility of actually living such life experiences and then turning them into literary artifacts have represented my special concern here. The sweet sharp thorns of this classic challenge in real life can make of it the inexhaustible literary theme confirmed by each one and all of these "three sophisticated ladies" in their splendid works.
\end{abstract}

Keywords: daughterhood, intertextuality, irony, metafiction, motherhood.

Irony and sharp wit will always distinguish a certain feminine rhetoric, rather intellectual than ideological; rather pragmatically achieved, perhaps, yet not devoid of passion and a certain type of (rather sarcastic) humor, since ridendo castigat mores.

Two things must be established from the very beginning: the first one is that, although not (half) as often included in syllabi bibliographies as their consecrated male fellow-writers, these three women writers are not minor writers. And the second one is that, despite this fact, feminism may not be the first safe label to attach to such writers as the ladies we will focus on here. They are: early twentieth 
century elegant New Yorker Edith Wharton, mid-twentieth century shocking Old Southern Flannery O'Connor, and last but not least, early twenty-first century intricate Canadian Alice Munro. On the contrary, if we have to establish influences and precursors, then these can only be: (Nathaniel Hawthorne via) Henry James for Edith Wharton; William Faulkner for Flannery O'Connor; and perhaps all of these American literary masters and disciples taken together, plus many others, from all over the world as far as Alice Munro is concerned.

At first sight, the main message of their short stories may even seem to oppose that of some not much older predecessors, like Kate Chopin, or Charlotte Perkins Gilman. Unlike the fin de siècle protagonists of Perkins Gilman's "The Yellow Wallpaper," and Chopin's The Awakening - the feminine main characters of Wharton's "The Old Maid," of O'Connor's "Good Country People," of Munro's "Silence" and "Corrie" evince no radical endeavours to get out of the "trap of marriage," or of that of any other kind of "traditional" relationships between a man and a woman, such as the (moral) bond between unmarried (or even extra-marital) couple partners. And yet the chastening meaning of the "realistic" life-choices made by such antiheroines may be at least as dramatic and intense - if not even more so - than that of Edna Pontellier's drowning suicide, or that of the woman locked between the four yellow-papered walls desperately surrendering to insanity.

Though apparently far away from each other in both time and space, these three "sophisticated ladies" will prove to speak the same language, which is not only English: it is a particular language of the mind, creating a multilayered rhetoric of fine, perverse psychological fiction, enhanced in all its raw strains of verisimilitude by cool detachment and a certain cerebral contemplation of their brilliant and strangely twisted life stories. These life stories have all kept their mark of every-day (anti-)heroism - which has actually earned these writers a passport to universality and also to the contemporary literary canon, irrespective of the century.

Despite the stylistic and setting differences among these unique stories, there are certain narrative motives by which they communicate, such as: the (hurt) hubris, the humiliation, and the horror of being a woman and having to deal with it in a men's world, and in the absence of men. And this message can only be conveyed by the ironic turns of discourse of minimalist feminine narrative. Alas: no scholarly classifications, no carefully established trends or fashions can make any difference here.

Hailed by Lloyd Morris, its first reviewer, as the best accomplishment of the entire volume ${ }^{1}$ - "The Old Maid: The 'Fifties" is the second one of the four novellas

1 In "Mrs. Wharton Looks at Society: In Four Novellettes She Re-creates Four Successive Decades in New York Life," published in New York Times Book Review, May 18, 1924, Lloyd Morris praises especially "The Old Maid," where "irony is the vehicle of concentrated tragic passion 
of which Edith Wharton's 1924 volume Old New York consists. They all form a symmetrical illo tempore pattern for the pun in the entire volume's title, anticipating an evocation of four fictive decades within a nineteenth century lost New York. The writer performs this imaginary (re)staging game, under the same compulsion of "a backward glance" - a phrase that she so dearly inherited from Walt Whitman, and which she would use again later as an echo in her 1934 memoirs book's title. "Old Walt" is likewise evoked in "The Spark: The 'Sixties," i.e. the third episode of Wharton's shorter fiction volume Old New York: Four Novellas.

"This is not a story-teller's story" (Wharton 2002, 187) - the narrator of "The Spark" warns us teasingly. The witty remark is actually valid for the entire assemblage of the four novellas. And moreover - none of these is free from intertextuality. If "The Spark" evokes (a possible image of) Walt Whitman and the Civil War (1861-1865), "The Old Maid” will make the reader return to Nathaniel Hawthorne's 1850 celebrated romance The Scarlet Letter and its similar narrative strategy of an apparent evocation of the past.

If Hawthorne's allegorically revisiting seventeenth century Puritan Boston results in the American chronotope of a universal story of guilt, remorse and innermost turmoil - then Wharton's revisiting Old New York of the midnineteenth century (when The Scarlet Letter was actually published, creating a scandal) will echo Hawthorne's story of guilt and remorse, in the finest possible fashion, proving that the dominant themes have remained quite contemporary if not (anymore) in fact, at least in fiction.

Narrative conciseness is one of the most demanding qualities that shorter fiction writers will strive to attain in their works. It is this distinct feature that characterizes such literary works as these we are just considering here. Whether written by Edith Wharton, Flannery O'Connor, or Alice Munro, the short stories we are discussing prove their authors' virtuosity in narrative suggestiveness by extreme concentration of material, and also by a rhetoric of understatement. What is left unsaid helps readers find between the lines all the room they may need for their imaginary contribution to the story, enhancing its dialogical dimension.

"The Old Maid" can be interpreted as a comedy of manners in miniature, so typical for Edith Wharton's narrative art. By completing the title with the historical interval - "The Fifties," i.e. the mid-nineteenth century - it should correspond to, the narrator can only imply that kind of Old New York mentality

which lifts the story high above the circumstances of narrow convention in which it arises, and makes it an austere and potent reading of life" (Wharton 2002, viii). This would be later confirmed by first rank literary critics of the twentieth century, such as R. W. B. Lewis, in his volume Edith Wharton (2002, 299). 
according to which marriage was a necessity for young women of a higher social rank. But is this view absolutely obsolete today?

And we may further wonder: who could be "the old maid" within this novella?

You could always have told, every one agreed afterward, that Charlotte Lovell was meant to be an old maid. Even before her illness it had been manifest: there was something prim about her in spite of her fiery hair. Lucky enough for her, poor girl, considering her wretched health in her youth: Mrs. James Ralston's contemporaries, for instance, remembered Charlotte as a mere ghost, coughing her lungs out - that, of course, had been the reason for her breaking her engagement with Joe Ralston. (Wharton 2002, 117; emphasis mine)

The narrator's voice can merely arouse the reader's suspicion by this insistence (see the italicized pronouns, implying the doubtful familiarity of common knowledge and commonsensical acceptance of a cliché) as to the anticipatory obviousness of Charlotte's fate. The emphasis is carried on:

So the James Ralstons had lent her their little farmhouse, and Mrs. Jim, with her extraordinary gift of taking things in at a glance, had at once arranged everything, and even pledged herself to look after the baby if Charlotte died. Charlotte did not die. She lived to grow robust and middle-aged, energetic and even tyrannical. And as the transformation in her character took place she became more and more like the typical old maid: precise, methodical, absorbed in trifles, and attaching an exaggerated importance to the smallest social and domestic observances. (Wharton 2002, 118; emphasis mine)

The repetition and the emphasis of the label-formula: "more and more like the typical old maid" builds up the skeleton of a narrative structure in which plot is condensed with all its segments, as if just wrapping up this skeleton. But the stronger the insistence, the greater the reader's doubt that this is the (kind of) story to be taken for granted. Moreover, this will enable the reader to surmise that "the old maid" is rather a social role that Charlotte Lovell must now learn well and assume for the rest of her life, for the sake of someone else, whom she loves more than herself.

Due to this ironic self-questioning structure of the literary text, we know already from the Part Two first pages that Charlotte has decided to put on the mask of spinsterhood. And soon enough we may infer that it is for the sake of her favourite "poor foundling" - Clementina/Tina, her own daughter by Clement/ Clem Spender.

Further on during the same paragraph we learn that "poor Jim Ralston was killed by a fall from his horse" $(2002,118)$ - which is enough to change the 
entire pattern of the narrative puzzle. Delia Ralston, his wife and Charlotte's first cousin, becomes now a young widow "with a boy and a girl to bring up;" therefore she will magnanimously take Charlotte and "Charlotte's foundling, too" home, to live with herself and her own children, under the same roof. "The little girl was called Tina Lovell: it was vaguely supposed that Charlotte had adopted her" (2002, 118; emphasis mine). Hence the household will be run now by the two women, raising (their) three children together.

Still the question remains open: who is "the old maid"?

As time goes by, Delia Ralston née Lovell regrets more and more her formerly conventional renouncing Clement Spender's love for the sake of the proper marriage to her late husband Jim Ralston. She realizes she sacrificed her soul in choosing social safety and welfare over true love. She comes to acknowledge and even envy her cousin Chatty's moral strength in having had rather a moment of passion followed by the birth of an illegitimate child: Clem's daughter, Tina.

As for Clem himself, his destiny is just as ironic as the fates of the two cousins gravitating around his memory: he becomes a docile husband to a decent wife, who would help him sell all his paintings to all their visiting American acquaintances, overseas. He may well never suspect that his accidental lovemaking to Chatty had resulted in Tina's birth. And that Delia, who had once rejected him, would eventually become the girl's legally adoptive mother - lest the old story should fatefully repeat itself. For fear that Tina might inherit her natural parents' passionate inclinations and recklessly ignore social convention, Delia Ralston decides to shelter her natural niece by the proper surname of Ralston, thus enabling Tina to get married to Lanning Halsey, the wealthy young man she sincerely loves, yet whose parents might otherwise never have allowed their union.

Therefore, "the old maid" cannot be Charlotte, Tina's natural mother; it cannot be Delia, whom Tina prefers to call "mother" - although compared to Delia's infatuation with Clem's and Chatty's daughter, Delia's affection for her own daughter appears no more than duty-bound. And fortunately, nor will "the old maid" be Tina, who gets "saved" by a last minute adoption launching her into the happy ending marriage to crown the story. "The Old Maid" is just a threatening label: either to be avoided by marriage (whether conventional or as a blessed love-match), or to be preferred as the least of two evils, compared to the even worse social status prospect of a mother whose child's father could not afford to marry her.

"The Old Maid" of Edith Wharton is evidently no fairy-tale, despite its conventional happy ending with the wedding that confirms a young couple's love-match. There is no room for fairy-tales in Edith Wharton's Old New York. All the more so, then, this perfect finale touch is employed in the same ironic mood, to keep the entire novella sealed by its waveringly bitter question-mark. 
Chatty and Delia are stuck with each other, in a love-hate relationship whose key is Tina - a constant reminder of much more than just Clem Spender: rather of the two cousins' failed youth. If Chatty feels she failed her youth chances by an act of passion, Delia considers to have failed her youth chances by the "wiser" determination to give up passion for ever. The irony of their opposite choices in life brings them together for Tina's sake. Hawthorne's Hester Prynne with her Pearl, facing together the Puritans' righteousness are never too far away from this New England romance background.

Yet this effort of raising together the lost love child is carried out rather as a competition than as a collaboration between Chatty and Delia. The polarity between hubris and humility forms the nucleus of Wharton's Old New York novella. And this hubris-humility double game is what dominates all the stories we are further here discussing: we shall see it at work in O'Connor's Old South story of forlorn Georgia, and then likewise in Munro's contemporary Canadian stories. From hubris to humility the only way for these non-heroic protagonists is that of (innermost stifled) double horror: the horror at facing the others' cynicism and the horror at being oneself ready for compromise. This (dis)balance between "pride and prejudice" has been perhaps the oldest double theme with modern women novelists, ever since Jane Austen. ${ }^{2}$

Charlotte will never ask for mercy and support from Delia - on the contrary; the novella plot in itself is such an ironic structure that it almost leads to Tina's "rescue" by Delia despite Chatty herself. Or at least apparently.

When she first comes to her much better off cousin Delia Ralston, Charlotte Lovell only needs advice from a happily married woman. Chatty confides in Delia and confesses to her, still nurturing the hope that she can both marry Joe Ralston, the cousin of Jim, Delia's husband, and keep her baby Tina, Clem Spender's love child:

Social tolerance was not dealt in the same measure to men and to women, and neither Delia nor Charlotte had ever wondered why: like all the young women of their class they simply bowed to the ineluctable. No; there was no escape from the dilemma. As clearly as it was Delia's duty to save Clem Spender's child, so clearly, also, she seemed destined to sacrifice his mistress. As the thought pressed on her she remembered Charlotte's wistful cry: "I want to be married, like all of you," and her heart tightened. But yet it must not be. (Wharton 2002, 105; emphasis mine)

2 This thematic pattern of realistic narrative can only function due to a specifically feminine gift for sharp wit. The way to this double horror of hurt hubris and humility also passes through some reference books and their women authors of the twentieth century, such as: The Philosopher's Pupil (1983) by Iris Murdoch; Possession (1990) by A. S. Byatt. Yet that line of digression should have to wait for now. 
Ironically, again, Delia should have been the last person for Chatty to have appealed to for advice: as an embodiment of social conformity and high bourgeois prejudice - moreover, as the true old flame of Clem Spender, who had found in Chatty's arms one night's comfort for his rejected love for Delia - Mrs. Jim Ralston could hardly be trusted for impartiality. ${ }^{3}$ Not only would Delia "sacrifice” Clem's mistress, but she would also take possession of their love child - as if "saving" the girl from poverty and social decay - and, by raising Tina with (at least) the same affection as she owed her own children, claim the girl's soul. Tina becomes Delia's property, regarding her not only as her benefactor, but also actually as her mother; Charlotte will remain "Aunt Chatty"- thus paying the price for her daughter's respectability and financial security in Old New York high life. Therefore, for Tina's sake, Chatty is finally deprived by everything and everyone, Tina included.

But the plot has its meanders until this is accomplished. Proud but poor Charlotte will first try to detach herself and her daughter from Delia's (perverse) protection. ${ }^{4}$ As soon as the girl shows her alarming attraction for Lanning Halsey, a charming young man, whose parents would never have allowed him to marry Chatty Lovell's daughter, Charlotte is ready to depart from Delia's home, withdrawing with Tina to some place suitable for their modest social condition. At this point, Delia is not yet ready to offer adoption. Instead, she tries to assure Chatty that her home would always be the place for all of them to share:

"I hope you exaggerate, Charlotte. There may be disinterested characters ... But, in any case, surely Tina need not be unhappy here, with us who love her so dearly." "Tina an old maid? Never!" Charlotte Lovell rose abruptly, her closed hand crashing down on the slender work-table. "My child shall have her life ... her own life ... whatever it cost me ...” (Wharton 2002, 131-132; ellipsis in the original, emphasis mine)

Therefore, playing the role of "the old maid," Charlotte had given up her right to a life of her own. Now she would have to also yield her daughter. To Tina, the happy bride to be, Aunt Chatty will never be more than a narrow-minded spinster with rigid rules. The only one who can understand her joy of living is

3 In her hypocrisy, devoted conformity and dull conventionalism, Delia Ralston should remind us of Adèle Ratignolle’s character in Kate Chopin's 1899 audacious novel The Awakening. Its tragic fin-de-siècle protagonist, Edna Pontellier, will commit suicide. Hers is the archetypal mask of "the fallen woman" - whereas Edith Wharton's Charlotte Lovell is a good survivor, as "the old maid." Chatty cannot afford any other "destiny:" she has to live for Tina, her daughter, cost what it may.

4 In 1939, the same year when Margaret Mitchell's emblematic Old South novel Gone with the Wind became a Hollywood cult movie, thus turning Vivien Leigh into our image of Scarlett O'Hara, Edith Wharton's novella "The Old Maid” was also adjusted for the silver screen. Bette Davis played Charlotte Lovell. It is significant that originally, Edmund Golding, the film director, had intended Bette Davis to play both Charlotte and Delia. According to his interpretation, then, Delia may represent Charlotte's alter-ego. 
Delia - the girl's accomplice-like foster-mother, and the kindly author of the true mother's utter defeat by alienation and annihilation.

Apart from its plot and its setting in mid-nineteenth century Old New York, with such labyrinthine windings sustained by classic verisimilitude - the essential requirement of realism in fiction - the beauty of such a cruel story stays in its stylistic achievement. Thus Edith Wharton's 1924 novella should be read as a modern story, with all its contemporary qualities acquired from psychoanalysis, enhancing its dramatization in both monologue and dialogue. ${ }^{5}$

High society respectability is ultimately a matter of money, of possession - and Charlotte can only use her intelligence in the best interest of her daughter, Tina, whose access to the exclusive world of Old New York comes at the price of her own mother's absolute self-denial.

From Edith Wharton's high modernist comedy of manners and elegant cityscape we have come now to a postmodern dark comedy. And yet, though published some good three decades later and taking us to a totally different American fictive setting, Flannery O'Connor's short story “Good Country People” from the volume A Good Man Is Hard to Find (1955) evolves in the same mode of failed motherhood and twisted daughterhood. ${ }^{6}$

The same selective omniscient narrator is recounting the grotesque story of Joy/Hulga Hopewell, Manley Pointer, Mrs. Hopewell - Joy's callous mother, and Mrs. Freeman - her tenant's ubiquitous wife. An all-pervasive sense of gloomy alienation and devastating meaninglessness remains suspended somewhere on the imaginary screen of this narrative. The story seems to unfold strictly on $a$ two-dimensional plane, rather like a sketch, hardly ever allowing the reader any insight into the characters' minds. The setting is a fictive Georgia countryside in the American Old South, where nothing much ever seems to happen. And yet.

What actually happens is that the characters' any attempt at communication is doomed to fail. Ridiculous (and almost harmless) as it may seem at first, an invasion of clichés, platitudes, truisms, prejudices becomes more and more threatening, until it catches under its net, of all characters, Joy/Hulga herself - ironically,

51924 remains a hallmark of high modernism in world literature: it is the year when Thomas Mann's masterpiece The Magic Mountain (Der Zauberberg) was first published. The first quality the two writers share is the sharp irony which yields their superb comedies of manners. Much like Mann's, Wharton's work obviously corresponds to this particular modern trend of psychoanalytical realism in world fiction. Like Thomas Mann, Edith Wharton is no "innovator" of narrative art. And yet, like both Thomas Mann and Henry James - her best literary friend Edith Wharton remains convincing in style and message until today.

6 "Before the story ends, however, O'Connor develops the most romantic scene in all her fiction. Bible salesman Manley Pointer, with his phallic name, and Joy/Hulga will try to seduce each other on a picnic with no food" (Whitt 1997, 77-78). 
the only one apparently safe, or who at least displays a certain aloofness and considers herself to be quite immune against all this empty everyday nonsense, which is the others' void "conversation."

Joy could be a cleverly masked alter-ego of the writer herself, a parody illustration of O'Connor's much debated anti-intellectualism. ${ }^{7}$ Her own vulnerability is symbolically expressed by her protagonist's artificial leg. Like Homer's legendary Achilles' heel, or like Melville's Captain Ahab's missing leg lost to Moby Dick - but then also like Flannery O'Connor's own lameness, due to her fatal lupus disease - Joy's missing leg signals her being a misfit. "Big spectacled Joy-Hulga" (O'Connor 2000, 275) is thirty-two years old, a Ph.D. in philosophy, an alleged atheist and nihilist:

Her name was really Joy but as soon as she was twenty-one and away from home, she had had it legally changed. Mrs. Hopewell was certain that she had thought and thought until she had hit upon the ugliest name in any language. Then she had gone and had the beautiful name, Joy, changed without telling her mother until after she had done it. Her legal name was Hulga. (O'Connor 2000, 274)

One of her major triumphs was that her mother had not been able to turn her dust into Joy, but the greater one was that she had been able to turn it herself into Hulga. (O’Connor 2000, 275)

(Un-/Re-)naming /entitling represents a matter of great concern for both mother and daughter. Joy (re)names herself Hulga, as soon as she comes of age. Then she earns her Ph.D. in philosophy, as if to even better mark the detachment between herself and her mother. Whereas the (divorced) mother, instead of feeling proud of her daughter's brilliant mind, of her exceptional scholarly and moral achievement, feels rather embarrassed by it, and also by her daughter's reading books of nihilistic philosophy, as if by some sort of monstrosity; as if by another form of (affective) lameness, of (mental) disability, preventing her daughter from "enjoying herself." As if this could only mar the girl's feeble chances to a conventionally successful femininity:

The girl had taken the Ph.D. in philosophy and this left Mrs. Hopewell at a complete loss. You could say, "My daughter is a nurse," or "My daughter is

$7 \quad$ In his Bakhtinian approach of Flannery O'Connor's work, Robert H. Brinkmeyer, Jr. makes a point of her anti-intellectual persona: "I'm not an intellectual and have a horror of making an idiot of myself with abstract statements and theories" - she writes in a letter. Yet Brinkmeyer, Jr. comments: "But of course O'Connor was an intellectual. As the scope and size of her personal library, together with her many references to her readings in her letters, attest, she was extremely well read, particularly (and not surprisingly) in literature and theology" (Brinkmeyer, Jr., 1993, 143). 
a schoolteacher," or even, "My daughter is a chemical engineer." You could not say, "My daughter is a philosopher." That was something that had ended with the Greeks and Romans. All day Joy sat on her neck in a deep chair, reading. Sometimes she went for walks but she didn't like dogs or cats or birds or flowers or nature or nice young men. She looked at nice young men as if she could smell their stupidity. (O’Connor 2000, 276)

On the other hand, the short story title voices the first and foremost of these invading truisms - like the vengeful furies in classic mythology. "Good Country People" is Mrs. Hopewell's phony way of referring to a most elusive social category, comprising the Freemans, whom she had hired to help her with all the work on her farm, and also Manley Pointer, the young Bible salesman, who comes into the picture as if out of the blue, selling Bibles: "Then she would tell how she had happened to hire the Freemans in the first place and how they were godsend to her and how she had had them four years. The reason for her keeping them so long was that they were not trash. They were good country people" (O'Connor 2000, 272; emphasis mine). Likewise, "good country people" is someone like Manley Pointer, the nineteen years old Bible salesman: "'I'm just a country boy.' He glanced up to her unfriendly face. 'People like you don't like to fool with country people like me!' 'Why!' she cried, 'good country people are the salt of the earth! Besides, we all have different ways of doing, it takes all kinds to make the world go 'round. That's life!'” (O'Connor 2000, 278-279; emphasis mine).

Reading this tough story twice, we may see that it is in this trap of nonsense and clichés - or rather trying to escape it - that Joy/Hulga falls prey to her perverse seducer, (whose name is not even) Manley Pointer. Compared to the philistinism of her mother, who has no use for a Bible, yet tries to find a convenient lie to mask this - Hulga's choice of atheism and nihilism represents a self-assumed attitude. She is ready to take the risks of her decision. Paradoxically, Hulga's claim to cynicism distinguishes her as the only one honest about her beliefs in the entire group of characters. And perhaps this is why she has to dearly pay for her exclusiveness. Her portrait drawn between hubris and humility cannot fit into this picture. The horror of it all stems from her own genuineness: from Hulga's arrogant claim to absolute authenticity.

On the other hand, the actually cynical character is Manley Pointer, who needs no philosophical system or vision to bluntly state his own view upon life and the world: '”And I'll tell you another thing, Hulga,' he said, using the name as if he didn't think much of it, 'you ain't so smart. I been believing in nothing ever since I was born!'” (O’Connor 2000, 291).

In competition with "good country people" like him, gullible/defiant Joy/ Hulga cannot but fail, despite her exceptional intelligence and learning: her missing leg, her heart condition, her poor eyesight are only the more evident 
of her vulnerable points. Besides she can still be suspected of a tender soul probably fatally wounded when she was ten and got shot in the leg by (an adult's) mistake, in a hunting accident, about which the reader will never learn much more except for the superficial details of fascinating horror, that Mrs. Freeman enjoys asking and getting from Mrs. Hopewell: "Hulga had heard Mrs. Hopewell give her the details of the hunting accident, how the leg had been literally blasted off, how she had never lost consciousness. Mrs. Freeman could listen to it any time as if it had happened an hour ago" (O’Connor 2000, 275). It is Joy's girl's soul that Hulga is doing her best to hide. Yet the shock that gives her the final blow will also take the reader by surprise.

When Hulga and Manley decide to go for a picnic, each one of them secretly plans to seduce the other. Joy/Hulga makes the fatal mistake of underestimating her much younger partner, unable to anticipate the 180 degrees reversal of their entire situation. Up in the barn loft, where she will climb just to prove him that she is not at all embarrassed by her leg prosthesis, just like in a grotesque parody of an erotic prelude, Joy/Hulga allows Manley Pointer to take off both her eyeglasses and her artificial leg. Not only does he remove these: he takes possession of them - rather than of the girl, erotically - adding them up to his weirdly morbid collection of medical items from people with disabilities. Then he vanishes, leaving Joy/Hulga at a loss. End of the story.

Hulga's leg may be a grotesque and/or Gothic fetish - somehow reminding us of Berenice's teeth, in Edgar Allan Poe's homonymous short story. But at least in Poe's namesake story, Berenice's teeth were (supposed to be) "natural." There's nothing natural in Flannery O'Connor's "Good Country People.” Or perhaps just Manley Pointer's sordid and outrageous wickedness - which is as genuine as Joy/ Hulga's candid intelligence. The only perfect object of ugliness is Pointer's evil mind, where there is actually no room for any faith or vision, whether logical or just imaginary: there is only the absolute monster. And his confession reverses the entire meaning of the story - because O'Connor's story does have a meaning, which is (at least) double: aesthetic and moral.

Perhaps this is the most surprising aspect of the entire narrative: that it proves ourselves as readers to be still responsive to morally meaningful story-telling. That we are not (yet) as tough and as cynical (intellectuals or aesthetes) as we may delude ourselves to be. That our own artificial leg may still hurt. Now and then, when touched by a great artist in story-telling, like lovely Miss Flannery. ${ }^{8}$

8 Robert Giroux's recollection of his first encounter with Flannery O'Connor as her would-be editor is touching: "Robert Lowell brought her into my office late in February 1949. [. . .] Behind her soft-spoken speech, clear-eyed gaze and shy manner, I sensed a tremendous strength" (O’ Connor 2000, viii). 
The same allegorical fight between authenticity and philistinism (and also pharisaic conformity) is rendered in Alice Munro's short story "Corrie," from her volume Dear Life. The most obvious affinity between O'Connor's Joy/Hulga and Munro's Corrie is their symbolical lameness and their bold defying refusal to regard themselves as defeated by it:

She led the way and he was able to see what he hadn't been sure of before. She was lame in one leg. "Isn't it a steep climb back up?" he asked. "I'm not an invalid." "I see you've got a rowboat," he said, meaning that as a partway apology. "I'd take you out in it but not right now. Now we've got to watch the sunset." She pointed out an old kitchen chair that she said was for watching the sunset, and demanded that he sit there. She herself sat on the grass. He was about to ask if she would be able to get up all right, but thought better of it. "I had polio," she said. "That's all it is. My mother had it too, and she died." "That's too bad." "I suppose so. I can't remember her." (Munro 2013, 156-157; emphasis mine)

If O'Connor's Hulga defies-and-denies her mother, Mrs. Hopewell, by rejecting her original name, Joy, which obviously did not fit her - Munro's Corrie can hardly cling to any memory of her mother, Mrs. Carlton, who died of the same disease from which she herself suffers.

Not only are both Hulga and Corrie brave and bold: they also initiate their games of sexual seduction. And they are likewise cheated and betrayed in their expectations: like O'Connor's Manley Pointer, so is Munro's Howard Ritchie focused on material profit, albeit of a more prosaic kind and less shocking than a medical prosthesis: it is cash, pure and simple. And while Howard Ritchie is an architect, even "a church architect" - as Mr. Carlton regards him - he also pretends to care about religion, just like Manley Pointer, in a philistine and pharisaic manner, that should have deluded no one, least of all (self-deluded) cynical Corrie:

The fact that he had produced a condom did not mean that he was a regular seducer. In fact, she was only the second person he had gone to bed with, the first being his wife. He had been brought up in a fiercely religious household and still believed in God, to some extent. He kept that secret from his wife, who would have made a joke of it, being very left-wing.

Corrie said she was glad that what they were doing - what they had just done - appeared not to bother him, in spite of his belief. She said that she herself had never had any time for God, because her father was enough to cope with. (Munro 2013, 158-159; emphasis mine) 
Alice Munro's dry humour is enhanced by the laconic selective omniscient narrator, whose austere rhetoric undermines the crisp yet unequal dialogue. What Howard says about himself contradicts himself; what Corrie never says about herself can only prove how far they are from each other. And how lonely she actually is. And how vulnerable, too.

Nothing can scare Corrie more than the perspective of their illicit love-affair coming to its end: "She made herself speak lightly, but she had gone deathly cold. For what if he said no? No, I can't let you. No, it's a sign. It's a sign that we have to stop. She was sure that there'd been something like that in his voice, and in his face. All that old sin stuff. Evil" (Munro 2013, 161; emphasis mine).

They were discussing bribe: the price they had to pay, in hard cash, for their "sinful liaison." This money would become Corrie's duty and "Lillian's ill-gotten gains." As the short story opens, Lillian Wolfe is a housemaid with the Carltons, father and daughter. Soon the wealthy Mr. Carlton dies and Corrie, in her late twenties, lets Lillian go away from their provincial town and get a job in the city. Howard then claims to have reencountered Lillian at a party in the city, where he had gone with his wife. Lillian would work there as a housemaid, employed by Ritchie's friends who had invited him over, together with his wife. Howard pretends that Lillian had blackmailed him, threatening to tell everything to his wife. This is how they find the bribing solution. Corrie offers to pay the money herself. Howard just has to deliver the sum twice a year, sending it to the p. o. box allegedly belonging to Lillian. And thus their unofficial relationship could carry on "safely" - for years, even decades on end: "Sometimes Corrie would fill up with tears, hiding her face against him. 'It's just that we're so lucky,' she said" (Munro 2013, 167; emphasis mine).

Meanwhile, advancing toward middle-age, Corrie has to prove her "superior woman" understanding and cope on her own with the time when Howard, living now in Toronto, will devote to his family. The Ritchies' holidays abroad, their expensive hobbies - all require money. Corrie suspects nothing, until one day. She had taken a voluntary job with the town's library, helping to recover long lost books. Intertextuality echoes and games of intricate masking and unmasking, indicating (belated) postmodern metafiction will intensify the story, (as if) illustrating a narcissistic narrative pattern - one of those defined by Linda Hutcheon, the celebrated contemporary Canadian theorist and critic of postmodern literature.

As she learns incidentally about Lillian Wolfe's unexpected death - at merely forty-six years of age, after some terrible illness - Corrie has "her finger in The Great Gatsby" (Munro 2013, 167). The forlorn library of the small town in Canada, where Corrie is the last one to care about the great American modern novel - about a love story culminating in catastrophic self-delusion - represents a symbolic place for a secular revelation moment. 
This moment of desperately repressed, silenced shock triggers in Corrie's mind the lucid understanding of the actual price she had been literally paying for her "lucky" love-affair with a married man. Or rather: the fact that it was her wouldbe lover (just a couple of years older than herself) whom she had been regularly paying. Horror at him and also at herself is all that remains after hubris and humility have filled and emptied the balance with their tormenting qualms.

And yet the story rounds up in a mode that - even if not altogether optimistic is not at all one of despondency. Compromise with oneself is a commonsensical, if not a heroic, solution - when all is said and done: "So that's the way they're going to leave it. Too late to do another thing. When there could have been worse, much worse" (Munro 2013, 174).

But silence is never safe in a story by Alice Munro. Narrative art has as much use for silence as music does. And the best illustration of this is the very short story with this self-contradicting title: "Silence" from Munro's volume Runaway. ${ }^{9}$

"Silence" is the third and last one of the Juliet stories, after "Chance" and "Soon." Therefore we may ascribe to this set of shorter narrative pieces the rank of a specific diegesis, with an anti-heroic feminine protagonist and her network of relationships with other literary characters, in various settings, at various moments of her sad and strange story of silenced solitude.

The Juliet of "Silence" is a Canadian Provincial Television star, having earned her popularity by leading a talk-show usually debating "Issues of the Day." Therefore she is involved in depicting everyday reality for some invisible audiences, who appreciate her for her public work. Juliet has thus become a quintessential protagonist of "purely" realistic fiction. Her professional career at this point represents a sort of mise-en-abyme reflection of the fiction she is also part of.

As a girl, Juliet had made some life choices that seemed to promise her quite a singular destiny for a young woman: she "had majored in Greek and Latin at college" $(2006,71)$, as we learn from "Chance" - the first story about Juliet. Much like Flannery O’Connor's Joy/Hulga, Alice Munro's Juliet makes a professional start marked by high intellectual vanity, which threatens to doom her to isolation later in her life. Her first job was that of teaching Greek mythology at a countryside

9 Presenting this volume, Jonathan Franzen, himself an American highly successful contemporary writer, uses an eight-argument critical demonstration of Alice Munro's narrative genius. He entitles his essay "INTRODUCTION: What Makes You So Sure You're Not the Evil One Yourself?" (Munro 2006). To my mind, even this title strangely echoes Flannery O'Connor's sarcastic titles, e.g. "The Life You Save May Be Your Own," a. s. o., thus providing us here with another (indirect) link, with another suggestion of affinity between the writers considered in the present essay. 
school, though "she was not a real teacher" $(2006,71)$, but then she said: "I love all that stuff. I really do" (2006, 71).

Juliet's acquaintance with Eric Porteous started by "chance," indeed. She learned he was a fisherman, some ten years older than herself; married to Ann, who got paralyzed after an accident, and died afterwards. When Juliet went to his village to look him up, his wife Ann was just being buried.

The next story about Juliet, "Soon," tells about her failure to reestablish a relationship with her parents, Sam and Sara; and especially about Juliet's tormenting sense of guilt at not having seen her mother still alive, for the last time:

Because it's what happens at home that you try to protect, as best you can, for as long as you can.

But she had not protected Sara. When Sara had said, soon I'll see Juliet, Juliet had found no reply. Could it have been managed? Why should it have been so difficult? Just to say Yes. To Sara it would have meant so much - to herself, surely, so little. But she had turned away, she had carried the tray to the kitchen, and there she washed and dried the cups and also the glass that had held grape soda. She had put everything away. (Munro 2006, 125)

As by some ironic fateful retribution, the story "Silence" shows Juliet herself as an abandoned mother. Her only child, Penelope, Juliet's daughter by Eric, soon to come of age, has been missing from home, for the first time since she was born, having left for "the Spiritual Balance Centre:"

"Because my daughter is there," Juliet says. "She's been on a retreat there or taking a course, I don't know what they call it. For six months. This is the first time I've got to see her, in six months."

"There are a couple of places like that, the woman says. They sort of come and go. I don't mean there's anything suspect about them. Just that they're generally off in the woods, you know, and don't have much to do with the community.

Well, what would be the point of a retreat if they did?"

She says that Juliet must be looking forward to seeing her daughter again, and Juliet says yes, very much.

"I'm spoiled," she says. "She's twenty years old, my daughter - she'll be twenty-one this month, actually - and we haven't been apart much.”

(Munro 2006, 127)

This is merely the ominous beginning of the story, depicting Juliet's dialogue with a casual acquaintance on the ferry taking her to "the Spiritual Balance Centre." From now on, the story will oscillate between, on the one hand, Juliet's 
memories of her daughter; of her fights with Eric and then of his death, while Penelope, thirteen years old then, was away from home on a trip with Heather, her best friend at school, and her family; and on the other hand, Juliet's continual and desperate efforts of ever finding Penelope again.

At first there seems to be some kind of hope, when the funny birthday card arrives on Penelope's birthday. The impersonality of this strictly conventional message puzzles Juliet:

Penelope did get in touch with Juliet, a couple of weeks later. A birthday card arrived on her own - Penelope's - birthday, the $19^{\text {th }}$ of June. Her twentyfirst birthday. It was the sort of card you send to an acquaintance whose tastes you cannot guess. Not a crude jokey card or a truly witty card or a sentimental card.

On the front of it was a small bouquet of pansies tied by a thin purple ribbon whose tail spelled out the words Happy Birthday. These words were repeated inside, with the words Wishing you a very added in gold letters above them. And there was no signature. Juliet thought at first that someone had sent this card to Penelope, and forgotten to sign it, and that she, Juliet, had opened it by mistake. Someone who had Penelope's name and date of her birth on file. Her dentist, maybe, or her driving teacher. But when she checked the writing on the envelope she saw that there had been no mistake - there was her own name, indeed, written in Penelope's own handwriting. (Munro 2006, 133)

"That unkind card" $(2006,133)$ was followed by a second one, within a year, in the same tormenting style. The mother reproaches herself having "neglected" her daughter's "spirituality," as "Mother Shipton" - the only one to whom Juliet had managed to talk at "the Spiritual Balance Centre" - had rebuked her.

Then, deserted by her daughter, little by little, Juliet withdraws from the world. She quits her successful local television job. She moves house. She finds some superficial comfort in ephemeral friendships. She resumes her Classical Studies, even with a view to eventually writing her Ph.D. thesis.

Then all of a sudden, after some solid years of silence, Juliet incidentally reencounters Heather, Penelope's former school friend:

And just about three weeks ago I was visiting Josh - you remember my brother Josh? - I was visiting my brother Josh and his family in Edmonton and I ran into Penelope. Just like this, in the street. No - actually it was in the mall, that humongous mall they have. She had a couple of her kids with her, she'd brought them down to get uniforms for that school they go to. The boys. We were both flabbergasted. I didn't know her right away but she recognized me. (Munro 2006, 154) 
Juliet asks the young woman how many children she has. When Heather says "three," she also adds up: "But my life's a picnic compared with Penelope's. Five" (Munro 2006, 155).

And this is as much as Juliet gets to ever learn about her daughter. The rest is the subdued mother's mere speculation, guesswork and despondent hope enough to fill in the story's final page. Before absolute silence.

Alice Munro's contemporary short stories "Silence" and "Corrie" will always remind me of Edith Wharton's elegant narrative style in depicting utter maternal defeat and self-denial. Likewise, they will always remind me of Flannery O'Connor's fine rendering of failed motherhood and disastrous daughterhood; also of O'Connor's so-called anti-intellectualism, which is nothing if not a plea for authenticity in literary narrative.

Last but not least, I shall always admire the stylistic virtuosity of each one and of all these three (in an echo from one of Duke Ellington's finest jazz tunes) sophisticated ladies of the short story in English. It is only in their exquisite ways of dealing with horror, (hurt) hubris and humility that they can make us readers aware of the horror, (hurt) hubris and humility of being a genuine woman and also writing like one.

\section{Works Cited}

Brinkmeyer, Jr., Robert H. 1993 [1989]. The Art and Vision of Flannery O'Connor. Baton Rouge and London: Louisiana State University Press.

Byatt, A. S. 1991 [1990]. Possession: A Romance. New York: Vintage International, Vintage Books, A Division of Random House, Inc.

Hutcheon, Linda. 2013 [1980]. Narcissistic Narrative: The Metafictional Paradox. Toronto: Wilfrid Laurier University Press.

Munro, Alice. 2006 [2004]. Runaway. With an Introduction by Jonathan Franzen. London: Vintage Books.

Munro, Alice. 2010 [2009]. Too Much Happiness. London: Vintage Books.

Munro, Alice. 2013 [2012]. Dear Life. London: Vintage Books.

Murdoch, Iris. 1984 [1983]. The Philosopher's Pupil. London: Penguin Books.

O'Connor, Flannery. 2000 [1971]. The Complete Stories. With an Introduction by Robert Giroux. New York: Farrar, Straus and Giroux.

Perkins Gilman, Charlotte. 1989 [1892]. The Yellow Wallpaper and Other Writings. With an Introduction by Lynne Sharon Schwartz. New York: Bantam Books. 
Wharton, Edith. 1964 [1905]. The House of Mirth. With an Afterword by Louis Auchincloss. New York: A Signet Classic from New American Library. Wharton, Edith. 1993 [1920]. The Age of Innocence. With an Introduction by R. W. B. Lewis. New York: Collier Books, Macmillan Publishing Company. Wharton, Edith. 2002 [1924]. Old New York: Four Novellas. With an Introduction by Lloyd Morris. New York: Pocket Books.

Whitt, Margaret Earley. 1997 [1995]. Understanding Flannery O’Connor. Columbia: University of South Carolina Press. 